\title{
Grand Challenge in Animal Nutrition
}

\author{
David L. Harmon* \\ Department of Animal and Food Sciences, College of Agriculture, Food and Environment, University of Kentucky, Lexington, \\ KY, United States
}

Keywords: nutrition, ruminant, poultry, swine, companion animal, research

A definition of "nutrition" appears as a simple concept "the act or process of nourishing or being nourished" (Merriam-Webster, 2020). While nourishing appears simple, the concept entails providing a growing list of nutrients that individually meet specific requirements. Animal nutrition research is predominantly targeted toward the commercial production of food and hence, efficiency. The optimization of that efficiency has long been a driving force in the design and implementation of animal nutrition research. While production efficiency remains a primary goal in animal nutrition research, societal concerns and improvements in the knowledge of animal nutritional physiology drive modern research objectives.

One of the fundamental concepts of nutrition is the study of nutrient utilization (Baker, 1986). Experiments such as these are the foundation of nutritional science as measures of nutrient balance or the biological response to a limiting nutrient are used to determine a requirement or to characterize a new feed ingredient. These methods often employ multiple or diverse species and models to ascertain or demonstrate a concept in a practical matter (Baker, 2008). It is anticipated that the objectives drive the choice of method or particular model in that a rat might serve as a model for a human or a cow depending on the scientific question to be answered.

The category of animal nutrition encompasses many species of livestock and companion animals. Within each species, there is a fundamental need to define nutrient requirements occurring throughout the production stage or life cycle. Plus, there may be contrasting goals as production agriculture strives for rapid growth whereas, companion animals may spend the majority of their existence as an adult at maintenance with the goal to maximize health and longevity. These goals may not be completely exclusive and thus, emphasize the need for a complete understanding and description of animal physiology behind the requirement and use for each nutrient.

Modern animal production relies on the synthesis of feeding systems that are derived from the compilation of research into models to predict nutrient needs and animal responses (Poppi and McLennan, 2010). Numerous such systems have been developed (NRC, 2006, 2016; Volden, 2011; INRA et al., 2018) and all have strengths and weaknesses. For example, amino acid needs for swine and poultry can be closely defined whereas these data for ruminants are still hindered by the complexity of the digestive process. Therefore, the efficacy of these models must be continually evaluated and challenged (Daniel et al., 2020). Future research must use the latest tools to continue to provide new inputs to further refine and validate these systems.

One perpetual challenge for nutrition research is the ever-changing nature of the subjects and production systems. Animal production continually selects for genetic improvement which can substantially change productivity, the efficiency of nutrient use, and nutrient requirements (Warner et al., 2007; Gidenne et al., 2017). This process is critical for meeting the increasing world food needs (Hume et al., 2011). The increasing demand for food must be met by increasing productivity and efficiency while decreasing environmental impact. To accomplish this, nutrition research plays a critical role. Manipulations such as altering carcass composition to increase lean can improve efficiency but requires changes in amino acid nutrition (Liao et al., 2015). Changes in amino acid nutrition must be optimal to minimize environmental impact (Tessari et al., 2016). Collectively, this scenario means that nutrition research is ever-evolving, changing as the animal changes and its 
needs are continually refined. Future research must continually adapt to address these needs.

Modern agricultural production is not without its issues and detractors. Substantial effort has been expended in the study of the environmental impacts of intensive animal production. A major issue that has been highly scrutinized is methane production by livestock and its contribution to global greenhouse gas production (Lassey, 2008). The goal here is not to debate the relevance or magnitude of the problem, or whether it is a lesser or greater problem than the efficiency of nitrogen use and its excretion by livestock (Calsamiglia et al., 2010) or other aspects of the environmental sustainability of livestock production (Rotz, 2020). Rather, our goal is to provide research that addresses these challenging problems, specifically, how to provide the optimal nutrition that results in minimal nutrient excretion or emission. Nutrition that produces meat, milk, or eggs with the lowest input and has the least impact on the environment or humankind. Research that provides a more desirable or healthier product (Burnett et al., 2020). These are all examples of issues that will drive research objectives in the future. Human health, environmental impact and product costs are all global concerns and these will drive consumer concerns and the need for animal nutrition research of the future. This must be done while increasing the production of food to meet the needs of a growing population.

Animal nutrition is driven by cost and providing the best nutrition at minimal cost will always determine the choice of inputs. To this end, the use and evaluation of potential feed sources for livestock is both historical (Quicke et al., 1959) and a critical component of modern livestock feeding and production (Luciano et al., 2020). The use of by-product feeds is critical to economical livestock production and research to evaluate new products and feed sources (McCusker et al., 2014) will continue to be a much needed and highly relative component of nutrition research. This area may be expanded with the growing demand for niche markets such as organic food production, the desire for less intensive, alternative production systems (Clay et al., 2020), and the world demand for a growing sustainable food supply (Beltran-Peña et al., 2020). All of these aspects will shape future nutrition research emphasis.

The concept of functional foods has generally been associated with human nutrition research (Domínguez Díaz et al., 2020).

\section{REFERENCES}

Al-Shawi, S. G., Dang, D. S., Yousif, A. Y., Al-Younis, Z. K., Najm, T. A., and Matarneh, S. K. (2020). The potential use of probiotics to improve animal health, efficiency, and meat quality: a review. Agriculture 10:452. doi: 10.3390/agriculture10100452

Baker, D. H. (1986). Problems and pitfalls in animal experiments designed to establish dietary requirements for essential nutrients. J. Nutr. 116, 2339-2349. doi: $10.1093 /$ jn $/ 116.12 .2339$

Baker, D. H. (2008). Animal models in nutrition research. J. Nutr. 138, 391-396. doi: $10.1093 /$ jn/138.2.391

Beltran-Peña, A., Rosa, L., and D'odorico, P. (2020). Global food self-sufficiency in the 21 st century under sustainable intensification of agriculture. Environ. Res. Lett. 15, 1-12. doi: 10.1088/1748-9326/ab9388
This is because of the relationship between health and longevity that is generally associated with living a long life whereas food production focuses on efficiency as opposed to longevity. However, many aspects of this functional food field are directly associated with improved nutrition, and many nutraceuticals that claim health-promoting properties have a role in animal agriculture (Gao et al., 2020). Their role may be increasing with the pressure to reduce the use of antibiotics in animal production (Oliveira et al., 2020). Natural feed additives (Cieslak et al., 2013) will play a role in animal production along with functional ingredients (Maqsood et al., 2020), probiotics (Al-Shawi et al., 2020), essential oils (Curabay et al., 2020), feed enzymes (Rossow et al., 2020), genetically modified grains (McNaughton et al., 2020), and many other functional ingredients. All will need to be evaluated in current production systems across multiple animal species.

In addition, functional foods of animal origin can be highly desired by consumers (Viana et al., 2020) and may play a role in improving human health (Moughan, 2020). The production of foods such as these, e.g., increasing the omega-3 composition of meat (Burnett et al., 2020), will require research on how the diet can be modified to produce this desired outcome. This will need to done while maintaining an eye on environmental impact and cost, thus it is just another of the many challenges ahead.

The study of nutrition is a never-ending journey to discover the optimum needs of every individual. Individual variation alone makes the journey an arduous one. Add to that continuous genetic improvement of each animal species and the challenge becomes optimizing needs for a moving target. It means the need for nutrition research is real and truly is never-ending. Future animal research will rely on familiar concepts but will expand the outcomes for a better view of the host and when coupled with the study of the genome will link these to the function of the endocrine system, the immune system, or the microbiome. All of these are influenced by nutrition, interact with the environment, and are keys to a better understanding of animal nutrition.

\section{AUTHOR CONTRIBUTIONS}

The author confirms being the sole contributor of this work and has approved it for publication.
Burnett, D. D., Legako, J. F., Phelps, K. J., and Gonzalez, J. M. (2020). Biology, strategies, and fresh meat consequences of manipulating the fatty acid composition of meat. J. Anim. Sci. 98:skaa033. doi: 10.1093/jas/skaa033

Calsamiglia, S., Ferret, A., Reynolds, C. K., Kristensen, N. B., and Van Vuuren, A. M. (2010). Strategies for optimizing nitrogen use by ruminants. Animal 4, 1184-1196. doi: 10.1017/S1751731110000911

Cieslak, A., Szumacher-Strabel, M., Stochmal, A., and Oleszek, W. (2013). Plant components with specific activities against rumen methanogens. Animal 7(Suppl. 2), 253-265. doi: 10.1017/S1751731113000852

Clay, N., Garnett, T., and Lorimer, J. (2020). Dairy intensification: drivers, impacts and alternatives. Ambio 49, 35-48. doi: 10.1007/s13280-019-01177-y

Curabay, B., Filya, I., and Canbolat, Ö. (2020). Effects of some essential oils on in vitro digestibility, rumen fermentation and methane gas production of alfalfa hay. Bursa Uludag Üniversitesi Ziraat Fakültesi Dergisi 34, 19-35. 
Available online at: https://dergipark.org.tr/tr/pub/bursauludagziraat/issue/ $54627 / 624426$

Daniel, J. B., Van Laar, H., Dijkstra, J., and Sauvant, D. (2020). Evaluation of predicted ration nutritional values by NRC (2001) and INRA (2018) feed evaluation systems, and implications for the prediction of milk response. $J$. Dairy Sci. 103,1-17. doi: 10.3168/jds.2020-18286

Domínguez Díaz, L., Fernández-Ruiz, V., and Cámara, M. (2020). The frontier between nutrition and pharma: the international regulatory framework of functional foods, food supplements and nutraceuticals. Crit. Rev. Food Sci. Nutr. 60, 1738-1746. doi: 10.1080/10408398.2019.1592107

Gao, X., Liu, J., Li, L., Liu, W., and Sun, M. (2020). A brief review of nutraceutical ingredients in gastrointestinal disorders: evidence and suggestions. Int. J. Mol. Sci. 21:1822. doi: 10.3390/ijms21051822

Gidenne, T., Garreau, H., Drouilhet, L., Aubert, C., and Maertens, L. (2017). Improving feed efficiency in rabbit production, a review on nutritional, technico-economical, genetic and environmental aspects. Anim. Feed Sci. Technol. 225, 109-122. doi: 10.1016/j.anifeedsci.2017.01.016

Hume, D. A., Whitelaw, C. B. A., and Archibald, A. L. (2011). The future of animal production: improving productivity and sustainability. J. Agric. Sci. 149, 9-16. doi,: 10.1017/S.0021859610001188

INRA, Noziere, P., Sauvant, D., and Delaby, L. (2018). INRA Feeding System for Ruminants. Wageningen: Wageningen Academic Publishers.

Lassey, K. R. (2008). Livestock methane emission and its perspective in the global methane cycle. Aust. J. Exp. Agric. 48, 114-118. doi: 10.1071/EA07220

Liao, S. F., Wang, T., and Regmi, N. (2015). Lysine nutrition in swine and the related monogastric animals: muscle protein biosynthesis and beyond. SpringerPlus 4:147. doi: 10.1186/s40064-015-0927-5

Luciano, A., Tretola, M., Ottoboni, M., Baldi, A., Cattaneo, D., and Pinotti, L. (2020). Potentials and challenges of former food products (Food Leftover) as alternative feed ingredients. Animals 10:125. doi: 10.3390/ani10010125

Maqsood, S., Adiamo, O., Ahmad, M., and Mudgil, P. (2020). Bioactive compounds from date fruit and seed as potential nutraceutical and functional food ingredients. Food Chem. 308:125522. doi: 10.1016/j.foodchem.2019.125522

McCusker, S., Buff, P. R., Yu, Z., and Fascetti, A. J. (2014). Amino acid content of selected plant, algae and insect species: a search for alternative protein sources for use in pet foods. J. Nutr. Sci. 3:e39. doi: 10.1017/jns.2014.33

McNaughton, J., Roberts, M., Smith, B., Carlson, A., Mathesius, C., Roper, J., et al. (2020). Evaluation of broiler performance and carcass yields when fed diets containing maize grain from transgenic product DP-2Ø2216-6. J. Appl. Poultry Res. 29, 700-711. doi: 10.1016/j.japr.2020.05.004

Merriam-Webster (2020). Merriam-Webster.Com Dictionary. Available online at: https://www.merriam-webster.com/dictionary/nutrition

Moughan, P. J. (2020). “Chapter 17 - milk proteins: a rich source of bioactives for developing functional foods," in Milk Proteins, 3rd Edn, eds M. Boland and H. Singh (Cambridge, MA: Academic Press), 633-649.
NRC (2006). Nutrient Requirements of Dogs and Cats. Washington, DC: The National Academies Press.

NRC (2016). Nutrient Requirements of Beef Cattle. Washington, DC: National Academy Press.

Oliveira, N., Gonçalves, B., Lee, S., Oliveira, C., and Corassin, C. (2020). Use of antibiotics in animal production and its impact on human health. J. Food Chem. Nanotechnol. 6, 40-47. doi: 10.17756/jfcn.2020-082

Poppi, D. P., and McLennan, S. R. (2010). Nutritional research to meet future challenges. Anim. Prod. Sci. 50, 329-338. doi: 10.1071/ AN09230

Quicke, G. V., Bentley, O. G., Scott, H. W., Johnson, R. R., and Moxon, A. L. (1959). Digestibility of soybean hulls and flakes and the in vitro digestibility of the cellulose in various milling by-products. J. Dairy Sci. 42, 185-186. doi: 10.3168/jds.S0022-0302(59)90543-0

Rossow, H. A., Golder, H. M., and Lean, I. J. (2020). Variation in milk production, fat, protein, and lactose responses to exogenous feed enzymes in dairy cows. Appl. Anim. Sci. 36, 292-307. doi: 10.15232/aas.2019-01943

Rotz, C. A. (2020). Environmental sustainability of livestock production. Meat Musc. Biol. 4, 1-18. doi: 10.22175/mmb.11103

Tessari, P., Lante, A., and Mosca, G. (2016). Essential amino acids: master regulators of nutrition and environmental footprint? Sci. Rep. 6:26074. doi: $10.1038 /$ srep 26074

Viana, M. M., Polizer Rocha, Y. J., Trindade, M. A., and Alfinito, S. (2020). Consumer preferences for burgers and milk desserts: evaluating the importance of health claim attributes. J. Sens. Stud. e12615. doi: 10.1111/joss. 12615

Volden, H. (2011). NorFor-The Nordic Feed Evaluation System. Wageningen: Wageningen Academic Publisher.

Warner, R. D., Pethick, D. W., Greenwood, P. L., Ponnampalam, E. N., Banks, R. G., and Hopkins, D. L. (2007). Unravelling the complex interactions between genetics, animal age and nutrition as they impact on tissue deposition, muscle characteristics and quality of Australian sheep meat. Aust. J. Exp. Agric. 47, 1229-1238. doi: 10.1071/EA0 7229

Conflict of Interest: The author declares that the research was conducted in the absence of any commercial or financial relationships that could be construed as a potential conflict of interest.

Copyright (c) 2020 Harmon. This is an open-access article distributed under the terms of the Creative Commons Attribution License (CC BY). The use, distribution or reproduction in other forums is permitted, provided the original author(s) and the copyright owner(s) are credited and that the original publication in this journal is cited, in accordance with accepted academic practice. No use, distribution or reproduction is permitted which does not comply with these terms. 